Article

\title{
The Dynamic Growth Exhibition and Accumulation of Cadmium of Pak Choi (Brassica campestris L. ssp. chinensis) Grown in Contaminated Soils
}

\author{
Hung-Yu Lai * and Bo-Ching Chen
}

Department of Post-Modern Agriculture, MingDao University, No. 369, Wenhua Rd., Peetow, Changhua County 52345, Taiwan

* Author to whom correspondence should be addressed; E-Mail: soil.lai@mdu.edu.tw; Tel.: +886-4-8876-660; Fax: +886-4-8871-516.

Received: 10 July 2013; in revised form: 10 October 2013 / Accepted: 14 October 2013 /

Published: 25 October 2013

\begin{abstract}
The accumulation of heavy metals, especially cadmium (Cd), in leafy vegetables was compared with other vegetables. Pak choi (Brassica campestris L. ssp. chinensis) is a leafy vegetable consumed in Taiwan and its safety for consumption after growing in contaminated soils is a public concern. A pot experiment (50 days) was conducted to understand the dynamic accumulation of $\mathrm{Cd}$ by pak choi grown in artificially contaminated soils. The edible parts of pak choi were sampled and analyzed every $2-3$ days. The dry weight (DW) of pak choi was an exponential function of leaf length, leaf width, and chlorophyll content. The accumulation of $\mathrm{Cd}$ increased when the soil $\mathrm{Cd}$ concentration was raised, but was kept at a constant level during different growth stages. Pak choi had a high bioconcentration factor $(\mathrm{BCF}=$ ratio of the concentration in the edible parts to that in the soils), at values of 3.5-4.0. The consumption of pak choi grown in soils contaminated at levels used in this study would result in the ingestion of impermissible amounts of $\mathrm{Cd}$ and could possibly have harmful effects on health.
\end{abstract}

Keywords: bioconcentration factor (BCF); cadmium (Cd); dynamic accumulation; pak choi 


\section{Introduction}

Soils contaminated with heavy metals (HMs) are major environmental problems throughout the world due to their adverse ecological effects. The remediation of HM-contaminated soils is a challenge because HMs do not degrade in the environment. Among the HMs, cadmium (Cd) contaminates soils primarily as a consequence of inappropriate disposal of industrial wastes, irrigation using contaminated water, application of fertilizers, or atmospheric deposition [1-3]. Cadmium is a non-essential element that has no metabolic use and is believed to cause damage even at low concentrations $[4,5]$. In plant tissues, excess $\mathrm{Cd}$ inhibits photosynthesis and respiration [6], and also reduces nutrient uptake [7]. The high mobility of $\mathrm{Cd}$ makes it easily taken up by crops, rapidly transferred to aerial parts, readily incorporated into the food chain, and consequently, a threat to human health $[8,9]$.

Farmland contamination with $\mathrm{Cd}$ was reported in the last decade, and the public is now paying more attention to the potential toxicity of ingested crops [10,11]. In 1982, some farmlands in northern Taiwan were contaminated with $\mathrm{Cd}$ as a result of irrigation using the illegal effluent from a nearby chemical factory. Paddy rice grown in these soils accumulated high concentration of $\mathrm{Cd}$ in their grains [12]. The Soil and Groundwater Pollution Remediation Act (SGWPR Act) announced by Environmental Protection Administration (EPA) of Taiwan uses Soil Control Standards (SCSs) as the threshold for identifying contamination. Contaminated sites should conduct necessary remediation practices when their total concentrations (aqua regia soluble) of HMs are beyond those recommended in the SCSs. For farmlands, the SCS for Cd is $5.0 \mathrm{mg} \mathrm{kg}^{-1}$. However, some genotypes of paddy rice accumulated more than $0.4 \mathrm{mg} \mathrm{Cd} \mathrm{kg}^{-1}$ (the regulative standard announced by Department of Health of Taiwan) in their grains even when the total Cd concentration in soils was less than the SCS [13].

Leafy vegetables accumulate higher concentrations of Cd than other crops $[9,14,15]$. It is predictable that leafy vegetables, like the popularly consumed pak choi, will accumulate harmful concentrations of $\mathrm{Cd}$ in the edible parts even when grown in soils containing low concentrations of Cd [16]. Many studies have been conducted to investigate the accumulation of $\mathrm{Cd}$ in harvest-ready leafy vegetables grown in soils with different $\mathrm{Cd}$ concentrations. To the author's knowledge, however, no study has yet been conducted to examine the dynamic accumulation of $\mathrm{Cd}$ at different growth stages. If the dynamic accumulation of $\mathrm{Cd}$ is known, the harvest of vegetables grown in contaminated soils could be changed to an acceptable period that would minimize the amount of accumulated $\mathrm{Cd}$ in the harvested parts. The main objectives of this study are: (1) to understand the dynamic accumulation of Cd by pak choi, and (2) to assess the risk of uptake of $\mathrm{Cd}$ at different growth stages in pak choi grown in soils with different contamination levels of $\mathrm{Cd}$.

\section{Experimental Section}

\subsection{Soil Preparation}

Soil samples were collected from the surface layer $(0-30 \mathrm{~cm})$ of an Inceptisol in central Taiwan. Soil samples were air dried, ground, and passed through 10, 80, or 100 mesh stainless steel sieves in accordance with different analyzing procedures. Basic soil characteristics of representative samples were then determined. Soil $\mathrm{pH}$ value (soil/water $=1 / 1 ; w / v$ ) was determined with $\mathrm{pH}$ meter (Mettler Toledo EL20, Columbus, OH, US) using a glass electrode [17]. The electrical conductivity (EC) of 
saturation extract was determined according to [18]. Soil particle size distribution was measured by a hydrometer [19]. Water content and water-holding capacity (WHC) were determined by gravimetric method [20]. Organic carbon (OC) content of ground and sieved (80 mesh) soil samples was determined by the Walkley-Black wet combustion method [21].

Total concentration of $\mathrm{Cd}$ in ground and sieved (100 mesh) soil samples $(3.0 \mathrm{~g})$ was determined following digestion in $28 \mathrm{~mL}$ of aqua regia $\left(7 \mathrm{~mL} \mathrm{HNO}_{3}+21 \mathrm{~mL} \mathrm{HCl}\right)$. Digests were filtered through Whatman No. 42 filter papers, made up to a $100 \mathrm{~mL}$ volume, and analyzed for Cd content with an AAnlyst 200 flame atomic absorption spectrometer (FAAS, PerkinElmer, Waltham, MA, US). Suitable volumes of solutions of $\mathrm{Cd}\left(\mathrm{NO}_{3}\right)_{2} \cdot 4 \mathrm{H}_{2} \mathrm{O}$ dissolved in deionized water (DI water) were sprayed on the sieved and air dried soil samples ( $5 \mathrm{mesh}$ ) to achieve their target $\mathrm{Cd}$ concentration (as an individual element) as: (1) Cd-CK: control with no Cd solution applied; (2) Cd-10: final total $\mathrm{Cd}$ concentration is $10 \mathrm{mg} \mathrm{kg}^{-1}$; and (3) Cd-20: final total Cd concentration is $20 \mathrm{mg} \mathrm{kg}^{-1}$. These artificially Cd-contaminated soils were subjected to three cycles of wet $(50 \%-70 \% \mathrm{WHC}) /$ dry (air-dried) incubation to simulate field conditions and to enable the added $\mathrm{Cd}$ to reach a steady state $[22,23]$.

\subsection{Pot Experiment}

Air-dried and artificially Cd-contaminated soil samples $(20.0 \mathrm{~kg})$ were placed in rectangular pots (L $64 \mathrm{~cm}, \mathrm{~W} 48 \mathrm{~cm}, \mathrm{H} 15 \mathrm{~cm}$ ). Solutions of $\mathrm{N}$ (as urea), P (in $\mathrm{KH}_{2} \mathrm{PO}_{4}$ ), and $\mathrm{K}$ (in $\mathrm{K}_{2} \mathrm{SO}_{4}$ ) were added at $1.0 \mathrm{~g} \mathrm{~N}, 0.44 \mathrm{~g} \mathrm{P}$, and $1.0 \mathrm{~g} \mathrm{~K} \mathrm{pot}^{-1}$ for all $\mathrm{Cd}$ treatments. A total of 130 pak choi (Brassica campestris L. ssp. chinensis) seeds were uniformly sown in each pot at about $1 \mathrm{~cm}$ depth from the soil surface. The pot experiment was conducted in a phytotron $\left(25^{\circ} \mathrm{C}\right.$, day/night $\left.=12 \mathrm{~h} / 12 \mathrm{~h}\right)$ for 50 days at MingDao University, with three replicates. Appropriate amounts of DI water were applied every 2-3 days to maintain soil moisture at 50\%-70\% WHC, which was determined by weighing the pot.

The edible parts of pak choi were sampled randomly every 3-4 days from day 15 th and 5-10 plants pot $^{-1}$ were harvested each time. The plant height $(\mathrm{H})$, leaf length $(\mathrm{L})$, and leaf width $(\mathrm{W})$ of the largest expanded leaf was determined and recorded immediately after harvest. The chlorophyll content of each expanded leaf was determined by a chlorophyll meter (SPAD-502, Konica Minolta, Osaka, Japan); these measurements had been found to correlate closely with actual leaf chlorophyll content [24]. The fresh weight (FW) of each plant was also determined and recorded immediately after harvest. Dry weight (DW) was determined and recorded after rinsing each plant part with tap water, flushing with DI water, and then oven drying at $65^{\circ} \mathrm{C}$ for $72 \mathrm{~h}$.

\subsection{Plant and Soil Analysis}

Ground tissues $(0.1-0.2 \mathrm{~g})$ were digested by $10 \mathrm{~mL}$ of mixed concentrated acid $\left(\mathrm{HNO}_{3} / \mathrm{HClO}_{4}=\right.$ $87 / 13$ by volume). After filtering through Whatman No. 42 filter papers and made up to $25 \mathrm{~mL}$, the digests were stored at $4{ }^{\circ} \mathrm{C}$ until further analysis. Soils were sampled and then air-dried and ground. Sieved (100 mesh) soil samples ( $3.0 \mathrm{~g})$ were digested by aqua regia, made up to $25 \mathrm{~mL}$, and filtered through Whatman No. 42 filter papers. The $\mathrm{Cd}$ concentrations in plant and soil digests were determined using a PerkinElmer AAnlyst 200 FAAS. 


\subsection{Quality Control and Statistical Analysis}

Certified reference materials of soil (CRM $143 \mathrm{R}$ ) and standard reference materials of tomato leaves (SRM 1573a) were used to monitor the accuracy of data. The data were considered valid when the recovery rate (actual concentration/certified concentration) in the digestion processes was in the range of $90 \%-110 \%$. Reagent blanks and three replicates of all samples were used to ensure accuracy and precision in the analysis. All of the quality control procedures conducted during the determination of $\mathrm{Cd}$ by FAAS followed NIEA M111.01C announced by Environmental Analysis Laboratory of Taiwan [25].

A statistical analysis was performed using SPSS (Statistical Package for Social Science, Armonk, NY, US). The differences in the growth rate and shoot $\mathrm{Cd}$ concentration among mean values of $\mathrm{Cd}$ treatments were evaluated by one-way analysis of variance (ANOVA) followed by LSD (least significant difference) test. Statistical significance was defined at the level of $p=0.05$.

\section{Results and Discussion}

\subsection{Basic Soil Characteristics}

The texture of the soil used was sandy loam (sand $64 \%$, silt $14 \%$, clay $22 \%$ ) with a moderate OC content (1.21\%) and neutral acidity (pH 7.72). Its EC was $0.39 \mathrm{dS} \mathrm{m}^{-1}$ which is less than the threshold $\left(4.0 \mathrm{dS} \mathrm{m}^{-1}\right)$ of a saline soil. The initial total $\mathrm{Cd}$ concentration in soil was $0.8 \pm 0.3 \mathrm{mg} \mathrm{kg}^{-1}$, which is less than the SCS of $5.0 \mathrm{mg} \mathrm{Cd} \mathrm{kg}$ imposed for farmlands in the SGWPR Act of Taiwan and can be regarded as a non-contaminated soil. After artificially spiking with $\mathrm{Cd}$ solutions, the final Cd concentration of Cd-10 and Cd-20 reached $10.5 \pm 0.2$ and $20.1 \pm 0.8 \mathrm{mg} \mathrm{kg}^{-1}$, respectively, which were close to the target concentrations.

Figure 1. The dynamic exhibition of leaf length, leaf width, plant height, and chlorophyll content (SPAD) of pak choi grown in (a) Cd-CK; (b) Cd-10; and (c) Cd-20. Replicates: $n=3$.

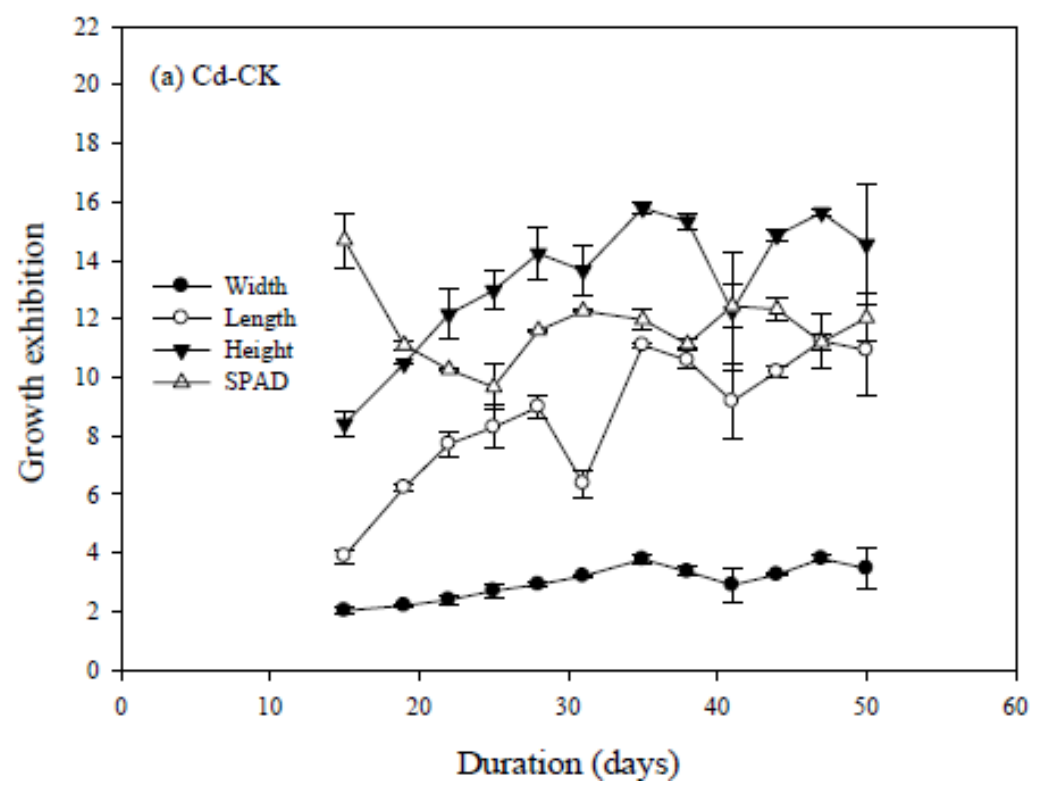


Figure 1. Cont.
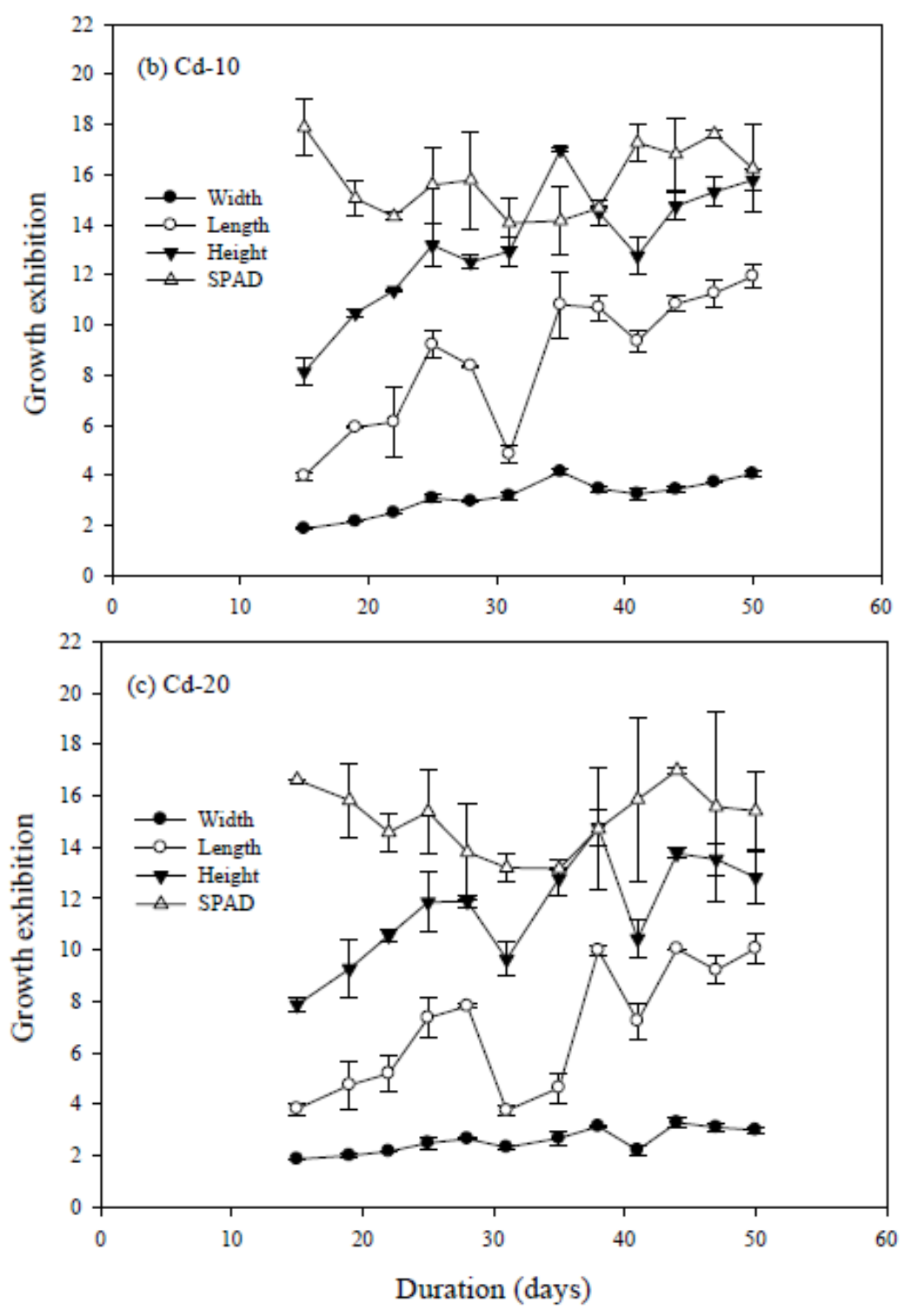

\subsection{Dynamic Change of Physiological Characteristics}

Figure 1 shows the dynamic exhibition of L, W, H, and SPAD for pak choi grown in artificially Cd-contaminated soils. In general, and except for SPAD, the L, W, and $\mathrm{H}$ increased with time. The L showed similar trends to $\mathrm{H}$, although some of the values were evidently reduced. Since no unhealthy plants were observed during the pot experiment and the growth of plants is irreversible, the plant $\mathrm{Cd}$ content will not decrease once increased. For the three $\mathrm{Cd}$ treatments, some of the measurements seemed to be unreasonable, namely days 31,35 , and day 41 . It is possible that these discrepancies resulted from sampling error, but it is difficult to explain the forgoing phenomena from the present data.

An exponential equation (Equation (1)) was used to describe the dynamic change in DW of edible parts with the growing time and some of the unreasonable data were excluded:

$$
\mathrm{DW}_{(\mathrm{t})}=\mathrm{DW}_{0} \cdot \mathrm{e}^{\mathrm{g} \cdot \mathrm{t}}
$$


where $\mathrm{DW}_{(\mathrm{t})}$ is the $\mathrm{DW}$ (g plant ${ }^{-1}$ ) at a given time (days), $\mathrm{DW}_{0}$ is the initial $\mathrm{DW}, \mathrm{g}$ is the growth rate $\left(\right.$ day $\left.^{-1}\right)$, and $t$ is a given time (days).

Exponential equations well described the change in DW at different growth stages (Figure 2). For the three $\mathrm{Cd}$ treatments, the growth rate was at the level of 0.046 to 0.051 and had good correlation coefficients $\left(r^{2}=0.947\right.$ to 0.970$)$.

Figure 2. The dynamic change of dry weight of pak choi grown in (a) Cd-CK; (b) Cd-10; and (c) Cd-20. Replicates: $n=3$.
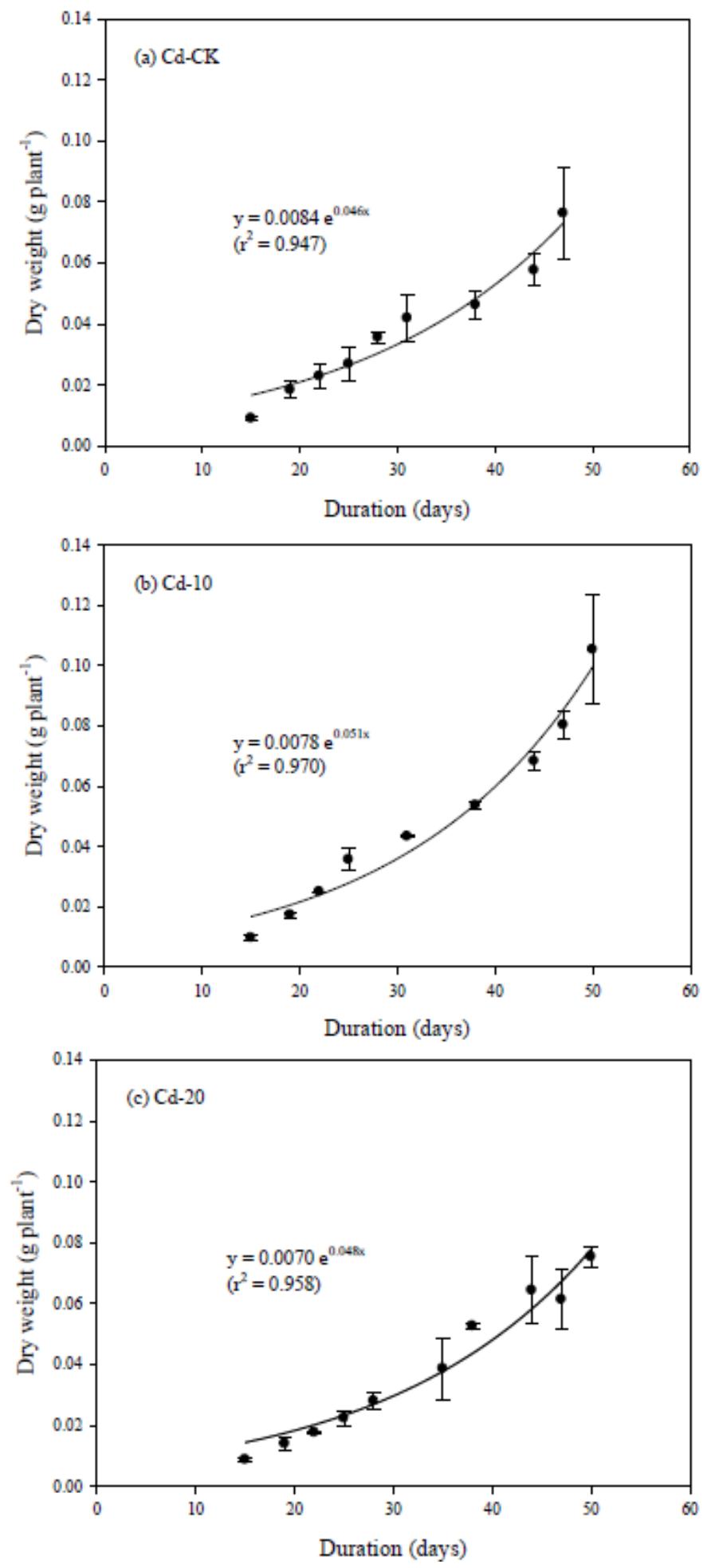
Even when growing in the Cd-treated soils, the growth rate for the $\mathrm{Cd}-10$ and $\mathrm{Cd}-20$ treatments showed a significant increase when compared to Cd-CK $(p<0.05)$, indicating that the growth of pak choi was not inhibited by the Cd concentration in soils. In agreement with a report by Chen et al. [16], the presence of $\mathrm{Cd}$ in soils promoted the growth of pak choi if the $\mathrm{Cd}$ concentration was below the toxic level.

\subsection{Relationships between Physiological Characteristics}

Nonlinear models using L, W, or SPAD were conducted by Cho et al. [26] to provide good representations of the leaf area (LA) and DW of cucumber. In this study, the physiological characteristics, namely L, $\mathrm{W}$, and SPAD, of the largest leaves of pak choi grown in each treatment were determined during the pot experiment. A stepwise-multiple regression was conducted to describe the relationship between predicted DW (DW predicted ) and the parameters determined, shown as Equation (2), with $\mathrm{r}^{2}$ of 0.893 .

$$
\begin{aligned}
\mathrm{DW}_{\text {predicted }}= & 0.0282 \times \mathrm{W}+0.00223 \times \mathrm{L}+0.00235 \times \mathrm{SPAD}-0.0894 \\
& \mathrm{DW}_{\text {predicted }}=0.893 \times \mathrm{DW}_{\text {determined }}+0.0047
\end{aligned}
$$

A significant linear relationship was found between the predicted DW and the determined DW $\left(\mathrm{DW}_{\text {determined }}\right)$ and the $\mathrm{r}^{2}$ was 0.945 (Figure 3).

Figure 3. Linear relationship between the determined dry weight and the predicted dry weight of pak choi grown in various Cd-contaminated soils.

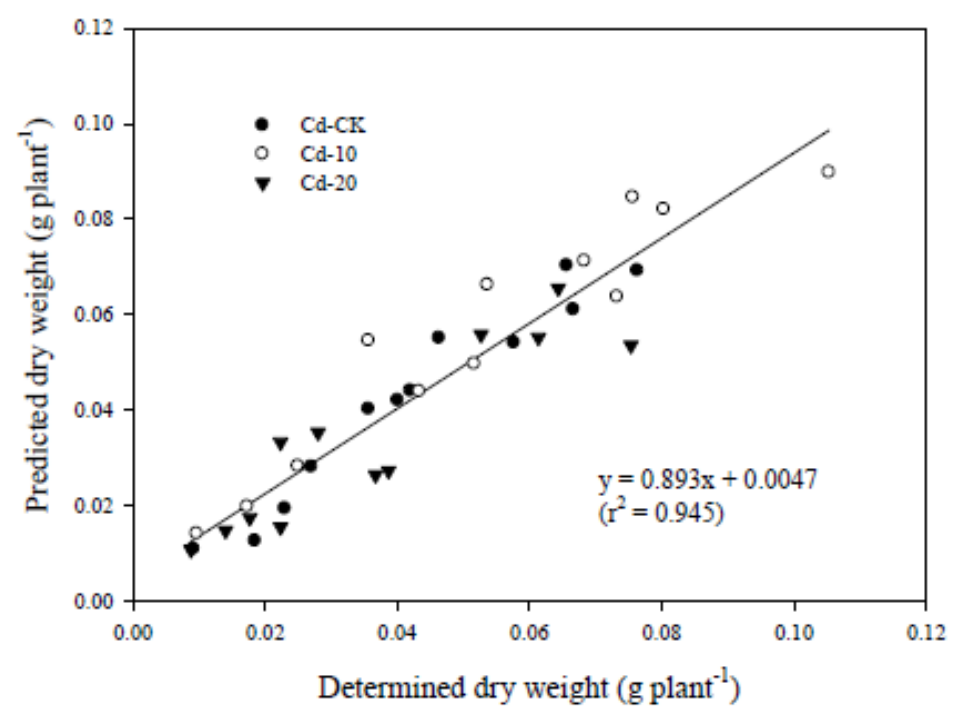

\subsection{Bioconcentration and Dynamic Changes in Accumulated Cd Concentration}

Figure 4 shows the dynamic changes in Cd concentration (DW based) in the edible parts of pak choi grown in various $\mathrm{Cd}$-contaminated soils. The accumulated $\mathrm{Cd}$ concentration significantly increased with increasing soil $\mathrm{Cd}$ concentration $(p<0.05)$. Although accumulated $\mathrm{Cd}$ concentrations changed at different growth stages, these changes were not drastic when the larger variations in some data were considered, and especially in Cd-20. 
Figure 4. The dynamic change of $\mathrm{Cd}$ concentration (dry weight based) in the edible parts of pak choi grown in various Cd-contaminated soils. Replicates: $n=3$.

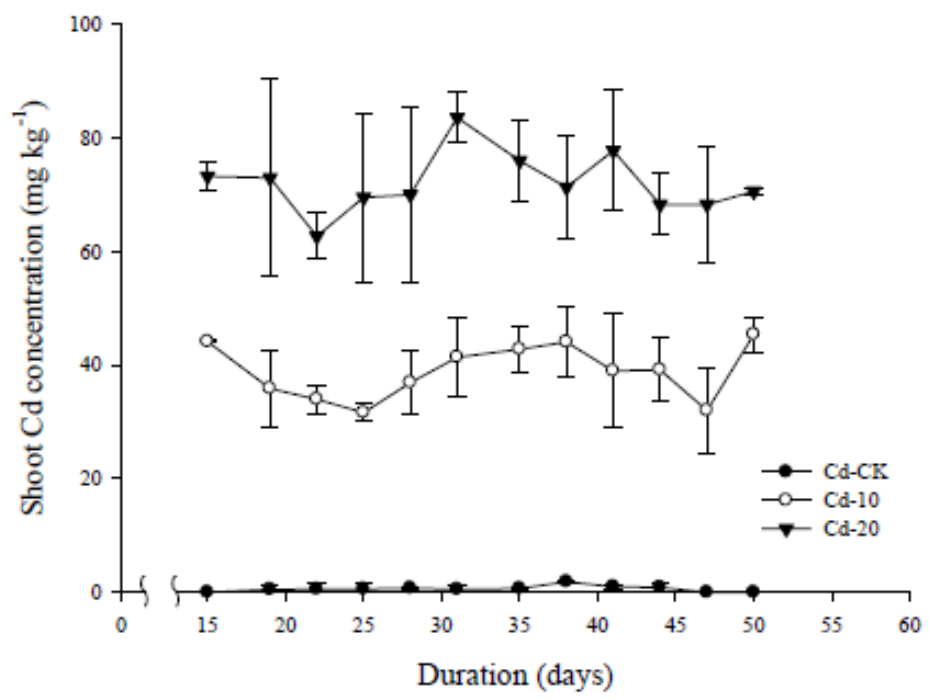

The accumulated $\mathrm{Cd}$ concentrations during day 15 and day 50 were in the range of $31-46 \mathrm{mg} \mathrm{kg}^{-1}$ (average $=38.9 \pm 4.8$ ) and $62-84 \mathrm{mg} \mathrm{kg}^{-1}$ (average $=72.0 \pm 5.3$ ) for Cd-10 and Cd-20, respectively. Chen et al. [16] used artificially Cd-contaminated soils and planted pak choi at various Cd levels. The tissue $\mathrm{Cd}$ concentrations in pak choi grown in Cd-2 and Cd-10 were approximately 40 and $70 \mathrm{mg} \mathrm{kg}^{-1}$, respectively, which is in agreement with these previous experimental results.

The dry weight based bioconcentration factor $\left(\mathrm{BCF}_{\mathrm{DW}}=\right.$ shoot $\mathrm{Cd}$ concentration/soil Cd concentration) was used to assess the accumulation capacity of pak choi. For Cd-10 and Cd-20, the BCF 3.96 and 3.59, respectively (Table 1). In comparison with other experiments that studied pak choi in Cd-contaminated soils at similar concentrations, the $\mathrm{BCF}_{\mathrm{DW}}$ reported in the present study was close to that reported by Chen et al. [16], but was approximately 1.7 -fold higher than that reported by Chen et al. [23]. The phytoavailability of $\mathrm{Cd}$ in soil is primarily controlled by soil $\mathrm{pH}$, redox potential, and cation exchange capacity (CEC) $[27,28]$. The mobility and phytoavailability of soil Cd increases when soil has a low $\mathrm{pH}$ value or CEC, which is mostly found in soils with a high sand content [29]. Compared with Chen et al. [23], the higher $\mathrm{BCF}_{\mathrm{DW}}$ found in the present study and in Chen et al. [16] was possibly a result of the coarser texture (lower CEC) and lower $\mathrm{pH}$ (5.5).

Table 1. The dry weight based bioconcentration factor $\left(\mathrm{BCF}_{\mathrm{DW}}\right)$ of pak choi grown in various Cd-contaminated soils for 50 days.

\begin{tabular}{|c|c|c|c|}
\hline \multirow{2}{*}{ Treatment } & Soil $\mathrm{Cd}$ conc. & Shoot $\mathrm{Cd}$ conc. & \multirow{2}{*}{$\mathbf{B C F}_{\mathrm{DW}}$ * } \\
\hline & \multicolumn{2}{|c|}{$\mathrm{mg} \cdot \mathrm{kg}^{-1}$} & \\
\hline $\mathrm{Cd}-\mathrm{CK}$ & $0.8 \pm 0.3^{\#}$ & $0.7 \pm 0.5$ & 0.80 \\
\hline $\mathrm{Cd}-10$ & $10.5 \pm 0.2$ & $38.9 \pm 0.8$ & 3.96 \\
\hline $\mathrm{Cd}-20$ & $20.1 \pm 0.8$ & $72.0 \pm 0.3$ & 3.59 \\
\hline
\end{tabular}

${ }^{*}$ mean \pm standard deviation; Replicates $(n=3) ; * \mathrm{BCF}_{\mathrm{DW}}=$ shoot $\mathrm{Cd}$ concentration (dry weight based)/soil Cd concentration. 
The continuous monitoring of yields during growth stages of different crops is difficult because destructive methods must be used. The development of non-destructive modeling can therefore be a very convenient and useful tool for the estimation of crop yields at various growth stages [26]. Similar to other regression models regarding L, W, LA, or SPAD for estimating crop production [23,30,31], a regression equation that used previous parameters was established in the present study to predict the DW of pak choi grown in Cd-contaminated soils. The modeled DW had a good linear relationship with the determined DW. This modeling (Equation (2)) can efficiently and accurately predict the DW at different growth stages without the need for destructive measurement.

The SPAD has been used both to determine the chlorophyll concentration of leaves and also to estimate the nitrogen status and to guide fertilizer-N timing on corn and rice [32-34]. It is an effective tool for non-destructive estimation of total chlorophyll concentration and content across a range of plant ages, growing conditions, and genotypes [24]. However, successful use of the SPAD meter can be influenced by soil type, crop variety, growth stage, leaf position, and the sampling point on the leaf $[32,35]$.

The LA plays an important role in photosynthesis and crop yield. Although LA was not determined in the present study, it can be expressed as $50 \%$ of the product of $\mathrm{L}$ and $\mathrm{W}$ if the shape of leaf of pak choi is considered as a diamond. Good linear relationships were observed between $50 \%$ of estimated LA and the total removal of Cd by the edible parts of pak choi grown in Cd-10 ( $\left.\mathrm{r}^{2}=0.806\right)$ and $\mathrm{Cd}-20$ $\left(\mathrm{r}^{2}=0.839\right)$ (Figure 5). When growing in Cd-contaminated soils, the total amount (mg plant $\left.{ }^{-1}\right)$ of $\mathrm{Cd}$ accumulated in the edible parts of pak choi increased because the estimated LA and DW increased, although the $\mathrm{Cd}$ concentrations did not change drastically. In other words, although the total mass of accumulated $\mathrm{Cd}$ increased with time, the increase in DW diluted the Cd concentration and thereby reduced the extent of the increase. However, it is difficult to distinguish between the effects resulting from dilution and from transpiration from the present data.

Figure 5. Linear relationship between 50\% of estimated leafy area and the total removal of $\mathrm{Cd}$ by the edible parts of pak choi grown in various Cd-contaminated soils for 50 days. Replicates: $n=3$.

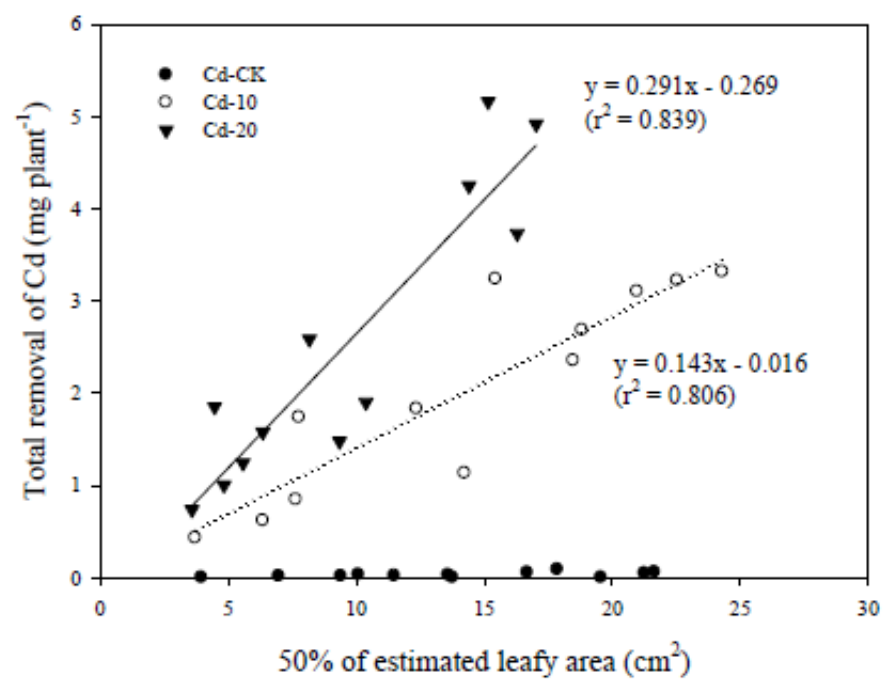

Once HMs enter the soil environment, they will react with soil particles and form different species, namely water soluble, exchangeable, or bound (to carbonates, organic matter, or oxides, etc.). In compliance 
with the strength of binding and phytoavailability, five fractions were separated by extracting with different chemical solutions [36]. The concentration of $\mathrm{HM}$ extracted by $1 \mathrm{M} \mathrm{MgCl}_{2}$ can represent the water soluble and exchangeable species, which should move with the soil solution. Because approximately $90 \%$ of the water taken up by plants will be lost through transpiration, LA dictates the amounts of water that pass through plant tissues and are lost from the stomata. During transpiration, the water soluble or exchangeable fractions of soil $\mathrm{Cd}$ will transfer together with water within plant tissues. The accumulation of $\mathrm{Cd}$ in plants is mainly driven by transpiration, which depends on LA, and higher transpiration generally leads to higher shoot Cd levels [37]. Plants thus accumulate more HM in their tissues if the transpiration rate is high or if most of the $\mathrm{Cd}$ in soils is primarily present as water soluble or exchangeable fractions. Soil samples from the pot experiment in the present study showed that approximately $19 \%$ to $27 \%$ of the total $\mathrm{Cd}$ in the soils could be extracted with $1 \mathrm{M} \mathrm{MgCl}_{2}$. There was a good linear relationship between this extractable $\mathrm{Cd}$ in the soil and that accumulated in the edible parts of pak choi $\left(r^{2}=0.918\right)$ (Figure 6). However, although the extractable soil Cd seems to be available for uptake into pak choi, further studies will be needed since only three Cd treatments were used in the present study.

Figure 6. Linear relationship between $1 \mathrm{M} \mathrm{MgCl}_{2}$ extractable $\mathrm{Cd}$ concentrations in soils and that accumulated in the edible parts of pak choi grown in various Cd-contaminated soils for 50 days. Replicates: $n=3$.

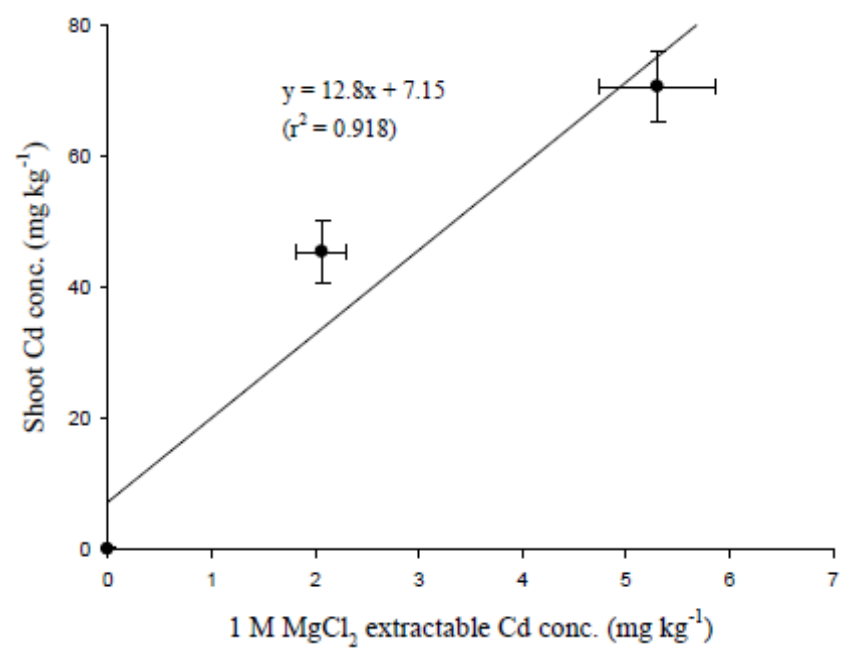

Regression of the FW based average Cd concentrations in the edible parts of pak choi grown in Cd-CK, Cd-10, and Cd-20 with soil Cd concentrations yielded a good linear relationship between $\mathrm{Cd}$ concentration in soil $\left(\mathrm{Cd}_{\text {soil }}\right)$ and the FW based $\mathrm{Cd}$ concentration in the edible parts $\left(\mathrm{Cd}_{\text {shoot }}\right)$ (Figure 7$)$. The $\mathrm{BCF}_{\mathrm{FW}}$ (slope of the linear regression) was 0.199, indicating that pak choi will accumulate 0.199-fold of the Cd concentration (FW based) in the soil in its edible parts when growing in artificially Cd-contaminated soils. In Taiwan, the SGWPR Act was announced in 2000 and SCS was used as a threshold for determining soil pollution. The SCS is $5.0 \mathrm{mg} \mathrm{kg}^{-1}$ for farmlands and $20 \mathrm{mg} \mathrm{kg}^{-1}$ for non-farmlands. Approximately $0.952 \mathrm{mg} \mathrm{kg}^{-1}$ (FW based) of Cd will accumulate in the edible parts of pak choi grown in soil contaminated with $5.0 \mathrm{mg} \mathrm{Cd} \mathrm{kg}^{-1}$ according to the $\mathrm{BCF}_{\mathrm{FW}}$ obtained in this study. Based on the daily consumption of vegetables suggested by Department of Health of Taiwan and if $300 \mathrm{~g}$ (FW based) of pak choi is consumed, the daily uptake of $\mathrm{Cd}$ for each person will reach 
$286 \mu \mathrm{g}$. This value is far beyond the provisional tolerable weekly intake (PTWI) (equal to $60 \mu \mathrm{g} \mathrm{day}^{-1}$ for an average adult weighing $60 \mathrm{~kg}$ ) suggested by Joint FAO-WHO Expert Committee on Food Additives [38]. The European Union maximum permitted concentrations in foodstuffs for leafy vegetables is $0.2 \mathrm{mg} \mathrm{kg}^{-1}$ (FW based). Using this $\mathrm{BCF}_{\mathrm{FW}}$ for pak choi, this vegetable will accumulate more than $0.2 \mathrm{mg} \mathrm{Cd} \mathrm{kg}^{-1}$ (FW based) if the soil Cd concentration reaches $1.23 \mathrm{mg} \mathrm{kg}^{-1}$. Therefore, pak choi should not be planted in Cd-contaminated soils where $\mathrm{Cd}$ is present at the concentrations used in this study because of the possible harmful effects due to consumption based on the available literature. However, aging of contaminated soil decreases HM phytoavailability $[39,40]$. The accumulation of $\mathrm{Cd}$ might be lower if pak choi is grown in soils where $\mathrm{Cd}$ contamination took place years earlier, unlike the artificially contaminated soils used in the present study. In addition, even after oral intake of pak choi, not all of the $\mathrm{Cd}$ contained within the edible parts will be trophically available because of subcellular compartmentalization [41].

Figure 7. Linear relationship between $\mathrm{Cd}$ concentrations in soils and that in the edible parts of pak choi grown in various Cd-contaminated soils for 50 days.

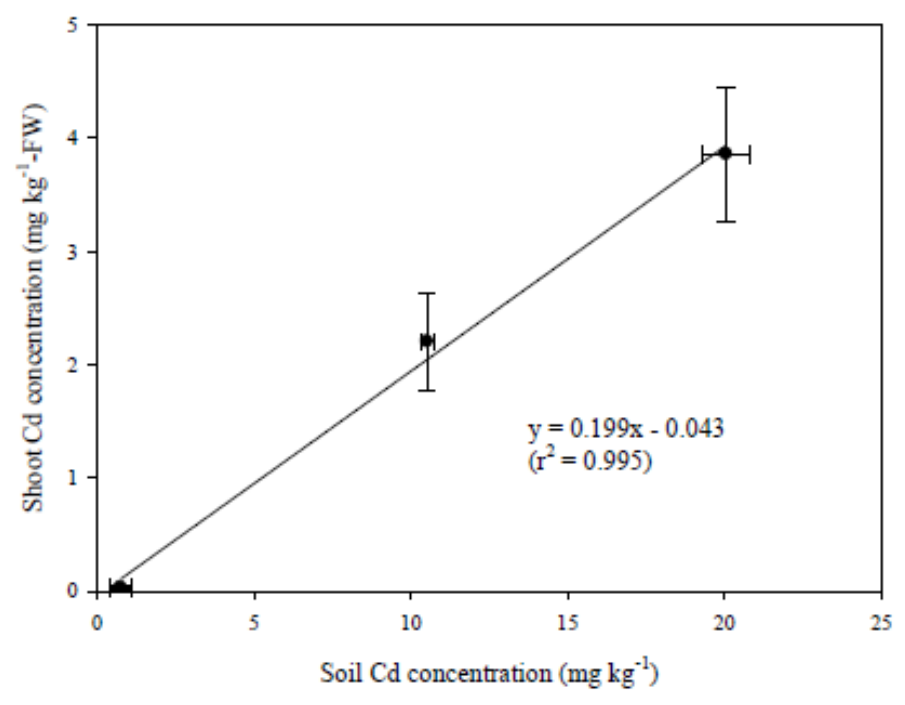

For the pak choi used in the present pot experiments, no drastic change was noted for the concentration of $\mathrm{Cd}$ in the edible parts regardless of soil concentration (Figure 4). The accumulated Cd concentration was only related to the $\mathrm{Cd}$ concentration in soil if the larger outliers in the data were disregarded. Oral intake of HMs from soil medium can be calculated by Equation (4) [42]:

$$
\text { Intake oral }- \text { soil }=\frac{C_{\text {soil }} \times I R_{\text {oral }}-\text { soil } \times E F \times E D}{B W \times A T} \times C F
$$

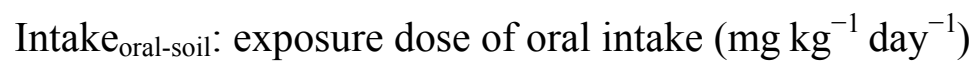

$\mathrm{C}_{\text {soil }}$ : concentration of concerned pollutant $\left(\mathrm{mg} \mathrm{kg}^{-1}\right)$

$\mathrm{IR}_{\text {oral-soil: }}$ ingestion rate $\left(\mathrm{mg}\right.$ day $^{-1}$ )

EF: exposure frequency (day year ${ }^{-1}$ )

ED: exposure period (year ${ }^{-1}$ )

BW: body weight $(\mathrm{kg})$

AT: average time (day) 


\section{$\mathrm{CF}$ : conversion factor $\left(\mathrm{kg} \mathrm{mg}^{-1}\right)$}

After determining the L, W, and SPAD of the largest leaf, one can predicted the DW of pak choi using Equation (2). If an allowable Intake oral-soil $_{1}$ is taken into account, the $\mathrm{IR}_{\text {oral-soil }}$ can be obtained for a given EF, ED, BW, and AT. Lai et al. [43] reported that the extension of growth period promoted the accumulation of $\mathrm{Cd}$ of different garden flowers. In Taiwan, a typical growing period for pak choi is 30 to 60 days. However, harvesting pak choi at early growing stages will not decrease the accumulated $\mathrm{Cd}$ concentration in the edible parts.

\section{Conclusions}

Experimental results of the presented study show that pak choi is a $\mathrm{Cd}$ accumulator which accumulated 3.5-4.0 times more $\mathrm{Cd}$ concentration than the soil concentration. Once it was grown in the Cd-contaminated soils, the Cd concentrations in the edible parts kept at a constant level during different growth stages. Both leaf area and soil $\mathrm{Cd}$ concentrations play important roles regarding the accumulation of Cd of pak choi.

\section{Acknowledgments}

The authors would like to thank the National Science Council of the Republic of China for financially supporting this research under Contract No. NSC 98-2313-B-451-002-MY3 and NSC 101-2621-M-451-002. Some instruments used in this research were financially supported by the MDU project coded P0990053.

\section{Conflicts of Interest}

The authors declare no conflict of interest.

\section{References}

1. Kim, S.J.; Chang, A.C.; Page, A.L.; Warneke, J.E. Relative concentrations of cadmium and zinc in tissue of selected food plants grown on sludge-treated soils. J. Environ. Qual. 1988, 17, 568-573.

2. Harrison, R.M.; Chirgawi, M.B. The assessment of air and soil as contributors of some trace-metals to vegetable plants. 3. Experiments with field-grown plants. Sci. Total Environ. 1989, 83, 47-62.

3. Jackson, A.P.; Alloway, B.J. The bioavailability of cadmium to lettuce and cabbage in soils previously treated with sewage sludges. Plant Soil 1991, 132, 179-186.

4. Wagner, G.J. Accumulation of cadmium in crop plants and its consequences to human health. Adv. Agron. 1993, 51, 173-212.

5. Das, P.; Samantaray, S.; Rout, G.R. Studies on cadmium toxicity in plants: A review. Environ. Pollut. 1997, 98, 29-36.

6. Mishra, V.K.; Tripathi, B.D. Concurrent removal and accumulation of heavy metals by the three aquatic macrophytes. Bioresour. Technol. 2008, 99, 7091-7097.

7. Hernandez, L.E.; Carpena-Ruiz, R.; Garate, A. Alterations in the mineral nutrition of pea seedlings exposed to cadmium. Plant Nutr. 1996, 19, 1581-1598. 
8. Soylak, M.; Tzen, M.; Souza, A.S.; Korn, M.G.A.; Ferreira, S.L.C. Optimization of microwave assisted digestion procedure for the determination of zinc, copper and nickel in tea samples employing flame atomic spectrometry. J. Hazard. Mater. 2007, 149, 264-268.

9. Yang, J.X.; Guo, H.T.; Ma, Y.B.; Wang, L.Q.; Wei, D.P.; Hua, L. Genotypic variations in the accumulation of exhibited by different vegetables. J. Environ. Sci. 2010, 22, 1246-1252.

10. Wang, X.L.; Sato, T.; Xing, B.S.; Tao, S. Health risks of heavy metals to the general public in Tianjin, China via consumption of vegetables and fish. Sci. Total Environ. 2005, 350, $28-37$.

11. Li, Y.; Wang, Y.B.; Gou, X.; Su, Y.B.; Wang, G. Risk assessment of heavy metals in soils and vegetables around non-ferrous metals mining and smelting sites, Baiyin, China. J. Environ. Sci. (China) 2006, 18, 1124-1134.

12. Chen, C.M.; Liu, M.C. Ecological risk assessment on a cadmium contaminated soil landfillA preliminary evaluation based on toxicity tests on local species and site-specific information. Sci. Total Environ. 2006, 359, 120-129.

13. Römkens, P.F.; Guo, H.Y.; Chu, C.L.; Liu, T.S.; Chiang, C.F.; Koopmans, G.F. Prediction of cadmium uptake by brown rice and derivation of soil-plant transfer models to improve soil protection guidelines. Environ. Pollut. 2009, 157, 2435-2444.

14. Alexander, P.D.; Alloway, B.J.; Dourado, A.M. Genotypic variations in the accumulation of Cd, $\mathrm{Cu}, \mathrm{Pb}$, and $\mathrm{Zn}$ exhibited by six commonly grown vegetables. Environ. Pollut. 2006, 144, 736-745.

15. Yang, Y.; Zhang, F.S.; Li, H.F.; Jiang, R.F. Accumulation of cadmium in the edible parts of six vegetable species grown in Cd-contaminated soils. J. Environ. Manag. 2009, 90, 1117-1122.

16. Chen, H.L.; Lai, H.Y.; Wang, S.M.; Kuo, Y.C.; Lu, C.J. Effect of biosolids and Cd/Pb interaction on the growth and $\mathrm{Cd}$ accumulation of Brassica rapa grown in Cd-contaminated soils. Water Air Soil Poll. 2010, 206, 385-394.

17. Thomas, G.W. Soil pH and Soil Acidity. In Methods of Soil Analysis, Part 3, Chemical Methods; Page, A.L., Sparks, D.L., Helmke, P.A., Loeppert, R.H., Soltanpour, P.N., Tabatabai, M.A., Johnston, C.T., Sumner, M.E., Eds.; ASA. Inc. and SSSA. Inc.: Madison, WI, USA, 1996; pp. 475-490.

18. Rhoades, J.D. Salinity: Electrical Conductivity and Total Dissolved Solids. In Methods of Soil Analysis, Part 3, Chemical Methods; Page, A.L., Sparks, D.L., Helmke, P.A., Loeppert, R.H., Soltanpour, P.N., Tabatabai, M.A., Johnston, C.T., Sumner, M.E., Eds.; ASA. Inc. and SSSA. Inc.: Madison, WI, USA, 1996; pp. 417-435.

19. Gee, G.W.; Bauder, J.W. Particle-Size Analysis. In Methods of Soil Analysis, Part 1, Physical and Mineralogical Methods, 2nd ed.; Klute, A., Campbell, G.S., Nielsen, D.R., Jackson, R.D., Mortland, M.M., Eds.; ASA. Inc. and SSSA. Inc.: Madison, WI, USA, 1986; pp. 383-412.

20. Gardner, W.H. Water Content. In Methods of Soil Analysis, Part 1, Physical and Mineralogical Methods, 2nd ed.; Klute, A., Campbell, G.S., Nielsen, D.R., Jackson, R.D., Mortland, M.M., Eds.; ASA. Inc. and SSSA. Inc.: Madison, WI, USA, 1986; pp. 493-544.

21. Nelson, D.W.; Sommers, L.E. Methods of Soil Analysis, Part 3, Chemical Methods; Page, A.L., Sparks, D.L., Helmke, P.A., Loeppert, R.H., Soltanpour, P.N., Tabatabai, M.A., Johnston, C.T., Sumner, M.E., Eds.; ASA. Inc. and SSSA. Inc.: Madison, WI, USA, 1996; pp. 961-1010.

22. Blaylock, M.J.; Salt, D.E.; Dushenkov, S.; Zakharova, O.; Gussman, C.; Kapulnik, Y.; Ensley, B.D.; Raskin, I. Enhanced accumulation of $\mathrm{Pb}$ in Indian mustard by soil-applied chelating agents. Environ. Sci. Technol. 1997, 31, 860-865. 
23. Chen, H.S.; Huang, Q.Y.; Liu, L.N.; Cai, P.; Liang, W.; Li, M. Poultry manure compost alleviates the phytotoxicity of soil cadmium: Influence on growth of pakchoi (Brassica chinensis L.). Pedosphere 2010, 20, 63-70.

24. Hawkins, T.S.; Gardiner, E.S.; Comer, G.S. Modeling the relationship between extractable chlorophyll and SPAD-502 readings for endangered plant species research. J. Nat. Conserv. 2009, 17, 123-127.

25. EPA/Taiwan. Flame Atomic Absorption Spectrometer. Method code No: NIEA M111.00C. Environmental Analysis Laboratory, Environmental Protection Administration of Taiwan: Taipei, Taiwan. 2002.

26. Cho, Y.Y.; Oh, S.B.; Oh, M.M.; Son, J.E. Estimation of individual leaf area, fresh weight, and dry weight of hydroponically grown cucumber (Cucumis sativus L.) using leaf length, width, and SPAD value. Sci. Hortic. 2007, 111, 330-334.

27. Kabata-Pendias, A.; Pendias, H. Trace Elements in Plants. In Trace Element in Soils and Plants, 3rd ed.; Kabata-Pendias, A., Pendias, H., Eds.; CRC Press: Boca Raton, FL, USA, 2001; pp. 7398.

28. Japenga, J.; Koopmans, G.F.; Song, J.; Römkens, P.F. A Feasibility test to estimate the duration of phytoextraction of heavy metals from polluted soils. Int. J. Phytoremediat. 2007, 9, 115-132.

29. Brady, N.C.; Weil, R.R. Soil Colloids: Seat of Soil Chemical and Physical Acidity. In The Nature and Properties of Soils; Brady, N.C., Weil, R.R., Eds.; Pearson Education Inc.: Upper Saddle River, NJ, USA, 2008; pp. 311-358.

30. Le Bail, M.; Jeuffroy, M.H.; Bouchard, C.; Barbottin, A. It is possible to forecast the grain quality and yield of different varieties of winter wheat from Minolta SPAD meter measurements. Eur. J. Agron. 2005, 23, 379-391.

31. Montero, F.J.; de Juan, J.A.; Cuesta, A.; Brasa, A. Nondestructive methods to estimate leaf area in vitis vinifera $\mathrm{L}$. HortScience 2000, 35, 696-698.

32. Huang, J.L.; He, F.; Cui, K.H.; Buresh, R.J.; Xu, B.; Gong, W.H.; Peng, S.B. Determination of optimal nitrogen rate for rice varieties using a chlorophyll meter. Field Crop. Res. 2008, 105, 70-80.

33. Lin, F.F.; Qiu, L.F.; Deng, J.S.; Shi, Y.Y.; Chen, L.S.; Wang, K. Investigation of SPAD meter-based indices for estimating rice nitrogen status. Comput. Electron. Agric. 2010, 71, S60-S65.

34. Yu, H.; Wu, H.S.; Wang, Z.J. Evaluation of SPAD and dualex for in-season corn nitrogen status estimation. Acta Agron. Sin. 2010, 36, 840-847.

35. Hussain, F.; Bronson, K.F.; Yadvinder, S.; Bijay, S.; Peng, S. Use of chlorophyll meter sufficiency indies for nitrogen management of irrigated rice in Asia. Agron. J. 2000, 92, 875-879.

36. Tessier, A.; Campbell, P.G.C.; Bisson, M. Sequential extraction procedure for the speciation of particulate trace metals. Anal. Chem. 1979, 51, 844-851.

37. Liu, X.; Peng, K.; Wang, A.; Lian, C.L.; Shen, Z.G. Cadmium accumulation and distribution in populations of Phytolacca Americana L. and the role of transpiration. Chemosphere 2010, 78, 1136-1141.

38. WHO. Fifty-Fifth Report of the Joint FAO/WHO Expert Committee on Food Additives. In $W H O$ Technical Report Series 901; World Health Organization: Geneva, Switzerland, 2001; pp. 61-69, 97-98.

39. Martinez, C.E.; Motto, H.L. Solubility of lead, zinc and copper added to mineral soils. Environ. Pollut. 2000, 107, 153-158. 
40. Wang, C.X.; Mo, Z.; Wang, H.; Wang, Z.J.; Cao, Z.H. The transportation, time-dependent distribution of heavy metals in paddy crops. Chemosphere 2003, 50, 717-723.

41. Wallace, W.G.; Lee, B.G.; Luoma, S.N. Subcellular compartmentalization of Cd and Zn in two bivalves. I. Significance of metal-sensitive fractions (MSF) and biologically detoxified metal (BDM). Mar. Ecol. Prog. Ser. 2003, 249, 183-197.

42. Lai, H.Y.; Hseu, Z.Y.; Chen, T.C.; Chen, B.C.; Guo, H.Y.; Chen, Z.S. Health risk-based assessment and management of heavy metals-contaminated soil sites in Taiwan. Int. J. Environ. Res. Public Health 2010a, 7, 3595-3614.

43. Lai, H.Y.; Juang, K.W.; Chen, Z.S. Large-area experiment on uptake of metals by twelve plant species growing in soils contaminated with multiple metals. Int. J. Phytoremediat. 2010, 12, 785797.

(C) 2013 by the authors; licensee MDPI, Basel, Switzerland. This article is an open access article distributed under the terms and conditions of the Creative Commons Attribution license (http://creativecommons.org/licenses/by/3.0/). 